\author{
Elżbieta Zębek \\ University of Warmia and Mazury in Olsztyn, Poland \\ ORCID: 0000-0002-8637-8391 \\ elzbieta.zebek@uwm.edu.pl
}

\title{
Humane Legal Protection of Homeless Animals
}

\author{
Humanitarna ochrona prawna zwierząt bezdomnych
}

\begin{abstract}
Animal rights at the international level have been defined in the Universal Declaration on Animal Welfare, which has become a guiding principle for many EU countries in shaping animal protection legislation. The subject of this article is the humane protection of homeless animals, which is the responsibility of the municipality in terms of maintaining cleanliness and order. The study assumes that by carrying out tasks regarding the protection of animals from homelessness, municipalities contribute to the effective protection of animals by providing them with appropriate care. The analysis found that the provisions of the Universal Declaration on Animal Welfare have been fully incorporated into Polish legislation. However, the effectiveness of the provisions on the protection of homeless animals executed by municipalities is not entirely satisfactory as evidenced by the post-inspection data and selected jurisprudence. In order to improve this state of affairs, the following de lege ferenda postulates were formulated, which in part are also guidelines of the Supreme Audit Office extending the catalog of activities in municipal homeless animal protection programs, introducing the requirement to inspect animal shelters by municipalities, changing the location requirements of animal shelters and also clarifying sanitary requirements concerning the conditions in which animals live in to improve their welfare. The above changes in legislation may contribute to more efficient humane protection of homeless animals in Poland and may serve as an example for other EU countries.
\end{abstract}

Keywords: protection of animals; municipality; homeless animals; municipal homeless animal protection programs; animal shelters

CORRESPONDENCE ADDRESS: Elżbieta Zębek, PhD, Associate Professor, University of Warmia and Mazury (Olsztyn), Faculty of Law and Administration, Department of International Public Law and European Union Law, Obitza 1, 10-750 Olsztyn, Poland. 


\section{INTRODUCTION}

As a living creature, an animal has the right to live in appropriate conditions which, in the case of domestic animals, depends on humans. Unfortunately, human behaviour towards animals is not always adequate to their needs. It should be noted that by taking an animal into our care, we become responsible for it. In many cases, pet owners behave irresponsibly by abandoning them, which causes them to become homeless. In the literature on the subject, much attention is paid to domestic, laboratory, farm and wild animals, especially in the aspect of criminal law, ${ }^{1}$ while the issue of homeless animals, which also require care and proper humane treatment, is discussed to a rather limited extent, which provides a certain novelty in this study.

The adoption of the Universal Declaration on Animal Welfare by UNESCO in 1978, was of great importance in shaping the regulations on animal protection in Poland which, due to its moral nature, became an argument for the adoption of new legislation on animal safety to stress their humane and legal protection. ${ }^{2}$ This is reflected in the Act of 21 August 1997 on the protection of animals, ${ }^{3}$ which, in addition to pets, farm animals, etc., also covers homeless animals. The legislator has imposed an obligation to take care of homeless animals in municipalities as part of their tasks related to maintaining cleanliness and order. However, there is a great deal of controversy regarding the very performance of these tasks by municipalities.

The subject of this research is the humane protection of homeless animals. This study assumes that the imposition of statutory obligations on municipalities in this regard allows for the effective legal protection of homeless animals, thus guaranteeing the rights of animals to safety and care. In order to verify this hypothesis, research question have been formulated: What is the legal status of animal pro-

${ }^{1}$ See W. Radecki, Ustawy o ochronie zwierzat. Komentarz, Warszawa 2015; A. Habuda, W. Radecki, Przepisy karne w ustawach w ochronie zwierząt oraz o doświadczeniach na zwierzętach, "Prokuratura i Prawo" 2008, no. 5, pp. 21-35; Prawna ochrona zwierzat, ed. M. Mozgawa, Lublin 2002; W. Radecki, Ustawy o ochronie zwierząt, o doświadczeniach na zwierzętach - z komentarzem, Warszawa 2007; G. Rejman, Ochrona prawna zwierząt, "Studia Iuridica" 2006, vol. 46; R. Węgrzynowicz, Ochrona zwierzat poddawanych doświadczeniom w świetle prawa i norm etycznych, "Eko i My. Poradnik ekologiczny" 2000, no. 9; W. Radecki, D. Danecka, Prawo łowieckie. Komentarz, Warszawa 2019; B. Rakoczy, R. Stec, A. Woźniak, Prawo łowieckie. Komentarz, Warszawa 2014; K. Mikulewicz, A. Kierejsza, E. Zębek, Zasady utrzymywania zwierząt gospodarskich - kontrowersje w materii sztuki legislacyjnej i wiedzy specjalistycznej, "Prawo i Środowisko" 2010, no. 1, pp. 102-109; E. Zębek, N. Kulbacka, International and National Legal Standards for the Protection of Wild Animals, [in:] Legal Protection of Animals, eds. E. Kruk, G. Lubeńczuk, H. Spasowska-Czarny, Lublin 2020, pp. 143-153.

2 J.-M. Neumann, The Universal Declaration of Animal Rights or the Creation of a New Equilibrium between Species, "Animal Law” 2012, vol. 19, pp. 91-109; M. Gibson, The Universal Declaration of Animal Welfare, "Deakin Law Review" 2011, vol. 16; A. Habuda, W. Radecki, op. cit., p. 24.

${ }^{3}$ Consolidated text, Journal of Laws 2020, item 638, hereinafter: APA. 
tection in Poland and is it sufficient for effective protection of homeless animals? This article aims to indicate the provisions concerning the rights of these animals and their protection, as well as the ways of implementing those tasks in terms of protection against homelessness included in maintaining cleanliness and order performed by municipalities and entities running animal shelters, and to determine the effectiveness of these activities.

The article uses a dogmatic and legal method consisting in the analysis of legal regulations regarding animal protection, with particular emphasis on the protection of homeless animals, and the literature on the subject including statistical data collected by the Supreme Audit Office in the scope of control of tasks implemented by municipalities concerning protection against animal homelessness, as well as selected jurisprudence.

\section{HUMANE PROTECTION OF HOMELESS ANIMALS}

\section{Humane protection of animals in international and domestic law}

Humane protection of animals in international law is reflected in the Universal Declaration on Animal Welfare, adopted by UNESCO on 15 October 1978 in Paris. The Preamble to this Declaration recognizes that every animal, as a living being, has rights in the moral sphere, and the recognition by the human species of the right of other animal species to existence is the basis for the coexistence of all living creatures. ${ }^{4}$ The animal rights mentioned in the Declaration, include the right to life and existence (Article 1), and to respect, care and protection (Article 2). Indeed, every animal belonging to a species traditionally living in a human environment has the right to live and grow at the rhythm and under the conditions of life and freedom peculiar to its species (Article 5). Animal rights should be legally protected just like human rights are (Article 14). When analysing the legal nature of the Universal Declaration on Animal Welfare, it appears that it cannot be attributed to the norms of international law. It is only a declaration of one of the specialised organisations in the UN system, which has a significant moral value but has no legal status. However, the acts of many countries include provisions contained in this Declaration, including the Polish Animal Protection Act. ${ }^{5}$ According to W. Radecki, from its content, we can distinguish two specific issues, imperative for the protection of animals, i.e. (1) recognition that an animal is not a thing - dereification, and (2) recognition that animals have rights - personification. ${ }^{6}$

${ }^{4}$ See more W. Radecki, Ustawy o ochronie zwierząt..., p. 41.

5 A. Habuda, W. Radecki, op. cit., p. 25.

${ }^{6}$ W. Radecki, Ustawy o ochronie zwierzat. Komentarz ..., p.43. 
In Polish legislation, animal rights are regulated in the Animal Protection Act. In Article $1 \mathrm{APA}$, the legislator declares that an animal, as a living being, is capable of suffering and is not a thing. The dereification of animals, i.e. the recognition that an animal is not a thing, is a very important legal provision. According to A. Habuda and W. Radecki, the legislator's assumption that animals are not things is the result of a departure from the ruthless anthropocentrism so heavily emphasized in the Universal Declaration on Animal Welfare. Normative dereification is very important in the axiological and socio-technical sense, as it has set out the canon of existing rules of behaviour towards animals in legal relations. An animal as a living creature, biologically related to mankind, has become the subject of rights and obligations. ${ }^{7}$ Consequently, humans owe animals respect, protection and care. Thus, each animal requires humane treatment (Article 5 APA), that takes into account an animal's needs and provides it with care and protection (Article 4 (2) APA). Humane treatment of animals applies to all animals, regardless of whether they are domestic, farm, wild or homeless. The considerations of this article are limited exclusively to homeless animals, encompassing domestic or farm animals that have run away, strayed or been abandoned by humans, and when it is not possible to identify their owner or any other person taking permanent care of them (Article 4 (16) APA).

\section{Humane protection of homeless animals as a municipal task}

Preventing animal homelessness and providing them with care is the responsibility of the municipalities (Article 11 APA). Thus, such a duty is the local government's own task which, in turn, means that it, at least formally, serves the needs of a given self-government community, ${ }^{8}$ and, in this case, it concerns protection against animal homelessness. As part of its obligation, the municipal council, by means of a resolution, shall determine by March 31, an annual program for the care of homeless animals and prevention of animal homelessness. This program includes, in particular: 1) providing homeless animals with a place in an animal shelter; 2) taking care of free-living cats, including their feeding; 3) catching homeless animals; 4) obligatory sterilisation or castration of animals in shelters; 5) searching for owners for homeless animals; 6) putting blind litters to sleep; 7) indicating a farm to ensure space for farm animals; and (8) enabling 24-hour veterinary care

${ }^{7}$ A. Habuda, W. Radecki, op. cit., p. 28; J. Białocerkiewicz, Status prawny zwierząt. Prawa zwierzą czy prawna ochrona zwierząt, Toruń 2005, p. 193; A. Elżanowski, T. Pietrzykowski, Zwierzęta jako nieosobowe podmioty prawa, [in:] Sprawiedliwość dla zwierząt, eds. B. Błońska, W. Gogłoza, W. Klaus, D. Woźniakowska-Fajst, Warszawa 2017, pp. 8-19.

${ }^{8}$ M. Rudy, Program opieki nad zwierzętami bezdomnymi oraz zapobiegania bezdomności zwierząt jako podstawowa forma realizacji zadania gminy z zakresu opieki nad zwierzętami, "Samorząd Terytorialny" 2018, no. 9. 
in cases of road incidents involving animals. The performance of the tasks listed in points 3-6 is entrusted to the entity operating the animal shelter (Article 11a APA).

Prevention of animal homelessness is carried out by the municipality within the scope of tasks concerning the maintenance of cleanliness and order in communes on the principles specified in the Act of 13 September 1996 on maintaining cleanliness and order in communes. ${ }^{9}$ According to Article 3 (2) (14) to (16) AMCOC, communes ensure cleanliness and order in their area and create conditions necessary for their maintenance and, in particular, prevent the homelessness of animals, as well as ensure the collection, transport and disposal of the corpses of homeless animals or parts thereof, along with collaboration with entrepreneurs undertaking activities in this respect.

As part of the implementation of these tasks, homeless animals are caught, which should be carried out in accordance with the principles set out in the Regulation of the Minister of Internal Affairs and Administration of 26 August 1998 on the principles and conditions of catching homeless animals, ${ }^{10}$ especially dogs and cats, which consists of trapping them by the entity with whom the municipality has signed an agreement for these services, transporting and placing the animal in a shelter $(\S 4)$. However, the equipment and means used for catching animals must not pose a threat to their life and health or cause them suffering ( $§ 7)$. It should be noted here that, in accordance with Article 11a APA, it is prohibited to trap homeless animals without providing them with a place in an animal shelter, unless the animal poses a serious threat to humans or other living creatures.

\section{Operating principles for animal shelters}

An animal shelter is an institution dedicated to homeless animals, mainly cats and dogs, where they are cared for - shelter, food and veterinary assistance. The legal status of animal shelters has been clarified in the Animal Protection Act, especially after its amendment in 2012. In accordance with the provisions of Article 4 (25) of this Act, an animal shelter is a place intended for the care of domestic animals. A permit of the right head mayor is required to run a shelter for homeless animals by entrepreneurs (Article 7 (1) AMCOC). Before deciding on the issue of the permit, the commune head, mayor or president of the town may ask the entrepreneur to supplement the missing documentation confirming that he or she meets the conditions specified by the law, which are required to perform the activity covered by the permit, as well as to check the facts provided in the application for the permit to determine whether the entrepreneur meets the conditions for performing the activity covered by the permit (Article 8a (1) AMCOC).

\footnotetext{
${ }^{9}$ Consolidated text, Journal of Laws 2020, item 1439, hereinafter: AMCOC.

${ }_{10}$ Journal of Laws 1998, no. 116, item 753.
} 
For an animal shelter to operate, it must meet the conditions specified in the Act of 11 March 2004 on the protection of animal health and combating infectious animal diseases. ${ }^{11}$ The Act lays down veterinary requirements for undertaking and carrying out activities in the field of, among others, running animal shelters (Article 1 (1) (j) of this Act). An entity conducting such activities is obliged to meet the veterinary requirements specified for a given type and scope of supervised activity. This applies to location, health, hygiene, sanitary, organisational, technical or technological requirements, protecting against epizootic or epidemic risks. These requirements include, in particular, the health condition of animals, construction works and individuals performing specific activities and the scope of such activities (Article 4(1) of this Act).

Detailed requirements concerning animal shelters are defined in the Regulation of the Minister of Agriculture and Rural Development of 23 June 2004 on detailed veterinary requirements for running animal shelters. ${ }^{12}$ With regard to the location conditions, an animal shelter should be at least $150 \mathrm{~m}$ away from human settlements, public utility facilities, plants producing products of animal origin, animal feed and establishments involved in the collection, storage, operation, processing, use or disposal of animal by-products, as well as slaughterhouses, markets, rallies, zoos or other animal gathering places. The area where the shelter is located should be paved and fenced $(\S 1)$. In the shelter itself, there should be separate rooms for medical and surgical procedures, isolating sick or those suspected of sickness, keeping healthy animals, i.e. males, females, females with nurseling, young separated from their mothers, as well as for storing veterinary medicinal products and medical devices, food, disinfectants, administrative and office work and documentation storage and a room for social purposes. Moreover, the animal shelter should have isolated rooms or boxes for quarantine and ensuring the separation of aggressive animals, as well as places for the release of animals from the shelter (§2). Pet rooms and boxes should be separated by partitions. Walls, floors and doors in these rooms or boxes should be made of materials that are easy to clean and disinfect, do not cause injuries to the animals and prevent escape. The animals should be able to move around freely, have a lair and permanent access to drinking water (§ 4). In addition, an enclosure should be provided to allow natural behaviour appropriate for the species $(\S 5)$.

An important obligation of the shelter manager established under the provisions of $\S 6$ (1) of the Regulation mentioned above is to keep records of the animals in the shelter with regard to: a) description of the animal, including its species, age, sex, colour and marking; b) date of admission to the shelter and details of the person putting the animal there; c) quarantine data; d) vaccinations and veterinary treatments which were carried out; e) date of leaving the shelter and details of the person

${ }^{11}$ Consolidated text, Journal of Laws 2020, item 1421.

12 Journal of Laws 2004, no. 158, item 1657. 
to whom the animal was handed over; and f) date of passing including its cause. The shelter manager should also keep a veterinary inspection book containing the recommendations of the veterinarian (§ 7). Only those individuals who are trained in the handling of animals and are well aware of animal protection regulations should be employed in the shelter ( $(8)$.

\section{ACTIVITIES OF MUNICIPALITIES AND ANIMAL SHELTERS - CONTROVERSIES}

Unfortunately, the actions of municipalities and shelters intended to protect animals from homelessness do not always comply with ethical and legal principles, as can be seen in the results of the Supreme Audit Office's inspection. The audit's goal was to assess the correctness and effectiveness of actions undertaken by municipalities to reduce animal homelessness. Based on the analysis of audit results, it was found that municipalities have taken several measures aimed at providing care to homeless animals, but they did not bring real results in the prevention of homelessness. As it turns out, most of the municipalities which were inspected carried out preventive measures to a limited extent (e.g. registration and marking of animals), but focused only on catching animals and transferring them to shelters. Therefore, measures to prevent homelessness were based merely on the functioning of shelters. According to the Supreme Audit Office, in the absence of preventive measures, the problem of animal homelessness will increase, generating higher and higher costs of maintaining a growing number of homeless animals. What is more, many municipalities have cooperated with entities not subject to veterinary supervision when organising care for homeless pets. The municipalities have also failed to enforce effective adoption measures by shelters, as shown by the low adoption rate of $23 \%$ among locked animals. However, one should also note the positive results of the inspection, which showed an improvement in the living conditions of animals in shelters compared with the previous inspection carried out back in 2012. Also, no notorious and drastic violations of animal welfare or sanitary standards were found. The inspection found that animals were provided with appropriate living conditions and care, including veterinary care. ${ }^{13}$

The recommendations of the Supreme Audit Office suggest that the activities of the municipality, which are limited primarily to catching and placing animals in shelters, do not prevent homelessness. Solving this problem requires comprehensive preventive measures, incorporating marking and recording of all animals and the introduction of real incentives to promote the castration and sterilisation of animals with owners. Placing animals in shelters and adopting them should be the last

${ }^{13}$ Najwyższa Izba Kontroli, Zapobieganie bezdomności zwierząt, Warszawa 2016. 
step in reducing homelessness. To this end, the Supreme Audit Office formulated proposals for changes in legislation on the performance of the tasks of municipalities regarding animal protection, which concerned, among others, extending the scope of financing by communes of the castration or sterilisation of animals living outside shelters with respect for the rights of their owners, launching an open catalog of tasks included in the program on protection against homelessness of pets, introducing a provision stating that the operation of a shelter may be permitted only after it has been ascertained that the veterinary requirements specified for the performance of this type of activity have been met, as well as the indication of the minimum area per specified animal in a room or box and the enclosure area in the 2014 Regulation. ${ }^{14}$

Irregularities in the implementation of the tasks of municipalities and entities in the field of protection of animals against homelessness are also evident in the case law. The jurisprudence indicates irregularities concerning the resolutions on the municipal program for the care of homeless animals and the prevention of homelessness of animals in violation of Article 11a (2) and (5) APA due to lack of indication, in the challenged resolution, of a specific shelter to which the homeless animals should be transported to and of an entity responsible for in catching them, as well as lack of regulations concerning the obligatory sterilisation or castration of animals in shelters. The consequence of the lack of indication in the disputed resolution of a specific animal shelter is the inability to carry out one of the basic tasks of such a program. ${ }^{15}$ The jurisprudence also describes many cases of violation of the provisions of Article 85 (1) (1) APA, regarding the conduct of the supervised activity, including operating animal shelters without meeting the veterinary requirements, e.g. not providing the animals with conditions that would protect them from cold, uncontrolled movement between boxes, failure to designate separate rooms for females with nurseling, failure to ensure the possibility of using appropriate enclosures and failure to separate healthy animals from sick animals. Often before signing a contract with such an entity, the municipality did not independently verify the conditions in the shelter. ${ }^{16}$ The jurisprudence also indicates irregularities in the location of a shelter in a place less than $150 \mathrm{~m}$ away from residential buildings, which is a breach of $\S 1$ (1) of the Regulation on detailed veterinary requirements for the operation of animal shelters of $2004 .{ }^{17}$ As a result, these facilities become very burdensome both for the local community and for the animals staying in these institutions.

${ }^{14}$ Ibidem, pp. 13-14.

15 Judgement of the Voivodeship Administrative Court in Lublin of 10 July 2014, II SA/Lu 909/13; judgement of the Voivodeship Administrative Court in Opole of 31 July 2014, II SA/Op $325 / 14$.

16 Judgement of the Court of Appeal in Łódź of 22 May 2015, I ACa 1733/14, LEX no. 1771324.

17 Judgement of the Voivodeship Administrative Court in Łódź of 11 March 2015, II SA/Łd 999/14, LEX no. 1792973. 


\section{DISCUSSION AND CONCLUSIONS}

Just like other animals, homeless pets have the right to live in suitable conditions, which is guaranteed by the Universal Declaration on Animal Welfare, which should be a canon and a guide for shaping national legislation on animal protection. When analysing the legal situation in Poland in this area, it should be stated that these rights have been implemented in the Animal Protection Act of 1997, both by indicating the right of an animal to life and care and by treating them humanely. Legal protection was also extended to homeless animals, albeit to a very limited extent in this legal Act due to assigning these tasks to municipalities as part of maintaining cleanliness and order contained in Article 3 (2) AMCOC. As part of these tasks, the municipalities were, among others, tasked to catch homeless animals and to set up animal shelters, which ought to meet the sanitary requirements specified in the Animal Protection Act of 1997 and in the Regulation of 2014. Therefore, the scope of regulations on the protection of homeless animals in the above-mentioned legal acts is quite wide and meets the demands of their humane treatment.

When analysing the extent to which the municipality was effective in completing the tasks directed towards protection against animal homelessness, it is necessary to start these deliberations from the very program of care for homeless pets and prevention of animal homelessness in the commune area. In this matter, we should agree with the guidelines and postulates of the Supreme Audit Office that the closed catalog of tasks of the program indicated in Article 11 APA may, to some extent, limit the capabilities of the municipality but, on the other hand, as it results from the jurisprudence, even this catalog is not fully indicated in the resolutions of the municipality council, so they are often challenged due to the inability to address the key issues, for instance, indicating a specific shelter or an entity dealing with catching abandoned animals, which makes these regulations ineffective in protecting animals from homelessness. Besides, in the view of the Supreme Audit Office, simply placing homeless animals in a shelter does not solve the problem, and preventive measures should also be introduced. This appears reasonable because if the number of domestic animals (dogs and cats) is lowered through such measures, the number of homeless people will be reduced as well. Educational activities must also be carried out on a wider scale by municipalities and social organisations dealing with animal protection, in order to make the public aware of their responsibility for the animals they nurture. Another significant legal shortcoming, also pointed out by the Supreme Audit Office, which should be agreed, is the fact that municipalities often fail to check the sanitary requirements of an animal shelter before issuing a permit for the entity to run such an institution. This can be regarded as negligence on the part of the municipality, but not as a result of violations of the provisions of the Act on maintaining cleanliness and 
order in communes, but rather because these provisions were not made obligatory. It, therefore, seems right to impose such an obligation on municipalities in order to prevent such situations. Furthermore, it will allow increased control over such entities, which will contribute to improving the welfare of animals in the shelter.

When analysing the operation of animal shelters, it must be stressed that they should operate particularly in pursuance of sanitary regulations, which is not always achieved in practice, as evidenced by the Supreme Audit Office inspections and jurisprudence. However, some of these irregularities are linked to the failure to clarify certain issues in the 2004 Regulation. This applies both to the location requirements, i.e. not maintaining a distance of at least $150 \mathrm{~m}$ from all facilities specified in $\S 1$ of the Regulation, as well as to the sanitary requirements themselves. In the case of the question regarding the location of an animal shelter, one should consider whether this distance of $150 \mathrm{~m}$ is not too short. Nevertheless, the animal shelter can be regarded as an enterprise which has a negative impact on the environment, e.g., through noise or odours. Furthermore, a longer distance would be less problematic, not only for people but also for the animals themselves, providing them with better living conditions by reducing the impact of the external environment. The legislator points to only those sectors of activity that concern products of animal origin, overlooking other projects such as expressways, railway lines and heavy industry plants. On the other hand, with regard to sanitary requirements, many issues were not specified in the 2004 Regulation, e.g. in the area of cubicles and rooms in which animals are housed, only the requirement of their free movement was indicated, which was also pointed out by the Supreme Audit Office. It is worth noting here that each species of animal has different preferences depending on its age. Such requirements are included, for instance, in relation to livestock, so why could such provisions not also be introduced for homeless animals staying in shelters? The lack of such clarification often results in too many animals being placed in the same room, which may reduce their comfort. The same goes for animal enclosures.

To sum up, to improve the effectiveness of the implementation of tasks in the field of humane protection of homeless animals within the framework of de lege ferenda postulates, the catalog of tasks of a municipality included in programs concerning the protection of animals from homelessness should be extended to include other activities not listed in it (open catalog), as well as the requirement of inspection of animal shelters by municipalities. The amendment of these regulations will allow for greater freedom of commune activities in this area and may contribute to a more effective application of these regulations, as well as strengthen supervision over entities running animal shelters. Another postulate is to increase the location requirements for animal shelters which will contribute to increasing the comfort of both the community living and doing business in the vicinity of such a facility and the animals themselves. Finally, the sanitary requirements regarding the room, boxes 
and enclosures for animals ought to be clarified in order to improve their wellbeing. The above changes in legislation may contribute to more effective humane protection of homeless animals and may also be a guide for other EU countries.

\section{REFERENCES}

\section{Literature}

Białocerkiewicz J., Status prawny zwierząt. Prawa zwierząt czy prawna ochrona zwierząt, Torun 2005.

Elżanowski A., Pietrzykowski T., Zwierzęta jako nieosobowe podmioty prawa, [in:] Sprawiedliwość dla zwierząt, eds. B. Błońska, W. Gogłoza, W. Klaus, D. Woźniakowska-Fajst, Warszawa 2017.

Gibson M., The Universal Declaration of Animal Welfare, "Deakin Law Review" 2011, vol. 16, DOI: https://doi.org/10.21153/dlr2011vol16no2art112.

Habuda A., Radecki W., Przepisy karne w ustawach w ochronie zwierząt oraz o doświadczeniach na zwierzętach, "Prokuratura i Prawo" 2008, no. 5.

Mikulewicz K., Kierejsza A., Zębek E., Zasady utrzymywania zwierząt gospodarskich - kontrowersje w materii sztuki legislacyjnej $i$ wiedzy specjalistycznej, "Prawo i Środowisko" 2010, no. 1.

Najwyższa Izba Kontroli, Zapobieganie bezdomności zwierzat, Warszawa 2016.

Neumann J.-M., The Universal Declaration of Animal Rights or the Creation of a New Equilibrium between Species, “Animal Law” 2012, vol. 19.

Prawna ochrona zwierzat, ed. M. Mozgawa, Lublin 2002.

Radecki W., Ustawy o ochronie zwierzat. Komentarz, Warszawa 2015.

Radecki W., Ustawy o ochronie zwierząt, o doświadczeniach na zwierzętach - z komentarzem, Warszawa 2007.

Radecki W., Danecka D., Prawo towieckie. Komentarz, Warszawa 2019.

Rakoczy B., Stec R., Woźniak A., Prawo łowieckie. Komentarz, Warszawa 2014.

Rejman G., Ochrona prawna zwierząt, "Studia Iuridica" 2006, vol. 46.

Rudy M., Program opieki nad zwierzętami bezdomnymi oraz zapobiegania bezdomności zwierząt jako podstawowa forma realizacji zadania gminy z zakresu opieki nad zwierzętami, "Samorząd Terytorialny" 2018, no. 9.

Węgrzynowicz R., Ochrona zwierząt poddawanych doświadczeniom w świetle prawa i norm etycznych, "Eko i My. Poradnik ekologiczny" 2000, no. 9.

Zębek E., Kulbacka N., International and National Legal Standards for the Protection of Wild Animals, [in:] Legal Protection of Animals, eds. E. Kruk, G. Lubeńczuk, H. Spasowska-Czarny, Lublin 2020.

\section{Legal acts}

Act of 13 September 1996 on maintaining cleanliness and order in communes (consolidated text, Journal of Laws 2020, item 1439).

Act of 21 August 1997 on the protection of animals (consolidated text, Journal of Laws 2020, item 638). Act of 11 March 2004 on the protection of animal health and combating infectious animal diseases (consolidated text, Journal of Laws 2020, item 1421).

Regulation of the Minister of Internal Affairs and Administration of 26 August 1998 on the principles and conditions of catching homeless animals (Journal of Laws 1998, no. 116, item 753).

Regulation of the Minister of Agriculture and Rural Development of 23 June 2004 on detailed veterinary requirements for running animal shelters (Journal of Laws 2004, no. 158, item 1657). 


\title{
Case law
}

Judgement of the Court of Appeal in Łódź of 22 May 2015, I ACa 1733/14, LEX no. 1771324. Judgement of the Voivodeship Administrative Court in Lublin of 10 July 2014, II SA/Lu 909/13. Judgement of the Voivodeship Administrative Court in Opole of 31 July 2014, II SA/Op 325/14. Judgement of the Voivodeship Administrative Court in Łódź of 11 March 2015, II SA/Łd 999/14, LEX no. 1792973.

\begin{abstract}
ABSTRAKT
Prawa zwierząt na forum międzynarodowym zostały określone w Światowej Deklaracji Praw Zwierząt, która stała się wytyczną dla wielu państw Unii Europejskiej (UE) w kształtowaniu przepisów w zakresie ochrony zwierząt. Przedmiotem analizy niniejszego artykułu jest humanitarna ochrona zwierząt bezdomnych, która jest obowiązkiem gminy w ramach utrzymania czystości i porządku. W pracy założono, że realizując zadania w zakresie ochrony zwierząt przed bezdomnością, gminy przyczyniają się do ich efektywnej ochrony poprzez zapewnienie im odpowiedniej opieki. W wyniku przeprowadzonej analizy stwierdzono, że w pełni wprowadzono postanowienia Światowej Deklaracji Praw Zwierząt do prawodawstwa polskiego, jednakże skuteczność przepisów w zakresie ochrony zwierząt bezdomnych przez gminy nie jest do końca skuteczna, czego potwierdzeniem są dane pokontrolne i wybrane orzecznictwo. W celu poprawy tego stanu sformułowano postulaty de lege ferenda, będące częściowo również wytycznymi Najwyższej Izby Kontroli, a mianowicie rozszerzenie katalogu działań $w$ gminnych programach ochrony zwierząt bezdomnych, wprowadzenie wymogu kontroli schronisk dla zwierząt przez gminy, zmianę wymogów lokalizacyjnych schronisk dla zwierząt, a także doprecyzowanie wymogów sanitarnych dotyczących warunków bytowania zwierząt w schroniskach dla poprawy ich dobrostanu. Powyższe zmiany w prawodawstwie mogą przyczynić się do bardziej efektywnej humanitarnej ochrony zwierząt bezdomnych w Polsce oraz mogą być wskazówką dla innych państw UE.
\end{abstract}

Słowa kluczowe: ochrona zwierząt; gmina; zwierzęta bezdomne; gminne programy ochrony zwierząt bezdomnych; schroniska dla zwierząt 